\title{
Dynamic Model of Land Use Change in Landslide Hazard Zones in Tanah Datar District, West Sumatra
}

\author{
*Indang Dewata \\ Departement of Environmental Science, Universitas Negeri Padang, Indonesia \\ Email: i_dewata@yahoo.com
}

*Corresponding Author, Received: May 10, 2019, Revised: May 15, 2019, Accepted: May 24, 2019

\begin{abstract}
Population growth has an impact on land resource needs, pressure on land use will have an impact on environmental degradation. As an effort to reduce pressure, policy efforts in land use are needed. This study aims to develop dynamic models in land use and develop land use policy direction. The method used in dynamic modeling uses system analysis and land change policy direction using ISM analysis. In dynamic modeling, land use change uses three scenarios, namely: optimistic scenario, murder scenario, and pessimistic scenario. In determining the direction of the policy involving all stakeholders as many as 15 experts. The results of dynamic model analysis show that forest area changes from time to time of 1.6 percent per year. Changes in forest areas will have an impact on increasing environmental disasters. As an effort to save the environment, there is a need for law enforcement and strict sanctions against perpetrators of forest area destruction.
\end{abstract}

Keywords: Dynamic model, Landslide, Hazard

\section{Introduction}

Landslides are a natural phenomenon that is influenced by many factors, uncontrolled land use can cause landslides (Hermon, 2009; Flentje and Chowdhury, 2016; Oktorie, 2017). In addition, the high intensity of rainfall causes the soil cavity to be filled with water, and forms a sloping area (Hermon, 2001; Mai and Smith, 2018). Today, landslides often occur in various parts of Indonesia, and landslides have caused property losses and loss of life (Hermon, 2010; Hermon, 2011; Abuzeinab, 2017; Hermon, 2017). Landslide disasters have caused the destruction of settlements and other facilities and infrastructure, so that it is necessary to restructure the settlements of the population into areas without landslides. During recent decades, the study of land use change has become a prominent research topic (Hermon, 2011; Hermon, 2012; Hermon, 2014; Hermon, 2015; Hermon, 2016), as change in land use has been recognized as one of the most important factors of environmental modification in the world. The land use refers to objects that represent human activities that results in the production of goods and services for society (Hermon, 2016).

Uncontrolled population growth affects land use. Built area will increase, but the water catchment area will be even faster (Utoyo et al., 2001; Umar, 2016; Umar and Dewata, 2017; Kristian and Oktorie, 2018; Hermon et al., 2018). Unbalanced and supported by the amount of water absorbed in the soil will encourage landslides during the rainy season (Harun, 1992; Canuti et al., 2013; Hermon, 2014; Umar et al., 2017). The dynamics of land use change for settlements are influenced by human movements in building settlements and the movement of regional functions, such as education, industry, trade, etc (Kustiawan, 1997; Virdin, 2001; Syahrin 2003; Suryani and Marisa, 2005; Martono et al., 2015; Oktorie, 2018). Furthermore, the rapid development will lead to changes in land use patterns, where built space increasingly dominates and urges natural spaces to change function. In addition, and explained that changes in land use patterns resulted in fluctuations in the carrying capacity of land resources, resulting in landslides (Sitorus, 2005; Xiao et al., 
2006; Mendoza et al., 2011; Hermon et al., 2019). Land use change has been recognized throughout the worldwide as one of the most important factors influencing the occurrence of landslides hazard around the world. Kaur et al., (2004) and Pribadi et al., (2006) explain that landslides are essentially caused by the inability of the soil to withstand loads above it because the soil has undergone degradation of soil properties.

Tanah Datar District has experienced an increase in landslides from both frequency and area affected in the period 2000-2017 (Glade, 2003). According to BPBD (2017); Huang and Zhao (2018), landslides can cause serious casualties dan severe damage to property. Furthermore,[22], explained the death toll caused by landslides worldwide is large. Disaster mitigation that can be done to minimize the impact of risk by determining the area of landslide hazard. Tanah Datar District based on physical characteristics has areas that are very prone to landslides, including: a) morphologically, around 55 percent of the area is relatively steep $(<27 \%)$; b) around 70 percent of the Limapuluh Kota District area primary forest area is converted into a secondary forest area; c) increasing rainfall intensity in the upper watershed area; and d) the development of the developed area. The growth of world population is currently increasing every year and requires a shorter period of time. The faster the growth of the world's population has an impact on increasing the need for land, especially for the development of residential areas. Limitations of the earth's surface space to support land needs for settlements have an impact on the use of land that is not in accordance with its designation. Tanah Datar District has a population growth rate of around 1.3 percent per year. High population growth increases the need for land for residential areas. While the physical characteristics of the Tanah Datar District area have many limiting factors to be used for residential areas, namely: a) relatively steep morphology, b) around 70 percent are primary forest areas, and c) are hazard to landslides and volcanic eruptions .

\section{Method}

The type of data used in this study is categorized into two types, namely primary data and secondary data. Primary data is generated from measurements and collection from the field, while secondary data is obtained from official documents, information and records from various relevant agencies. According to $[13,3,14]$ stated that some map needs in the dynamic model of land use in landslide hazard zone research are land use sourced from Landsat 7+ ETM imagery in 2010 and Landsat 8+ ETM imagery in 2017. When dynamic systems there is often a need to use assumption because; data may not exist for variables and we don't have empirical data about the future [23]. In the study of dynamic models of land use in the landslide hazard area a comparative analysis of land use was carried out with different interpretations of the time. The results of interpretation of changes in land use are analyzed using dynamic system approach. In the dynamic system approach there are several stages, including: needs analysis, problem identification, problem formulation, system identification, validation, model supplementation, and model evaluation.

To determine the direction of the policy using the Interpretative Structural Modeling (ISM) method. ISM is an established qualitative tool which can be applied in various disciplines [24]. The ISM method is effective enough to structure complex issues because it can be used to define and clarify issues, assess impacts and identify relationships between policies. Broadly speaking, the stages of the ISM method are as follows:

a) Decomposition of each element into several sub elements.

b) Determination of the contextual relationship between sub-elements in each element that shows pairwise comparisons there / no contextual relationships are used by expert opinions.

c) Structural Self Interaction Matrix (SSIM) using symbols V, A, X and O.

d) Making the Reachability Matrix (RM) table, replacing the symbols V, A, X and O with numbers 1 or 0.

e) Perform calculations based on transivity rules where the SSIM matrix is corrected until a closed matrix occurs.

f) Perform sub element level on each element according to vertical or horizontal levels. Preparation of the Power Dependence Driver (DPD) matrix for each sub element. Element classification is divided into four, including:

1) Quadrant I: Autonomous consists of sub elements that have driver power (DP) value $\leq 0.5 \mathrm{X}$ and dependence value $(\mathrm{D}) \leq 0.5 \mathrm{X}$. Where $\mathrm{X}$ is the number of sub elements in each element. Sub elements in quadrant I are generally not related to the system. 
2) Quadrant II: Dependent consists of sub elements which have a power driver (DP) value $\leq 0.5 X$ and dependence value (D) $\geq 0.5 \mathrm{X}$. Where $\mathrm{X}$ is the number of sub elements in each element. Sub elements in quadrant II are sub elements that depend on elements in quadrant III.

3) Quadrant III: Link (Linkage) consists of sub elements that have driver power (DP) value $\geq 0.5 \mathrm{X}$ and dependence value $(\mathrm{D}) \geq 0.5 \mathrm{X}$. Where $\mathrm{X}$ is the number of sub elements in each element. Sub elements that enter the third quadrant need to be studied carefully, because every action on one sub element will affect the other sub elements in quadrants II and IV.

4) Quadrant IV: Independent consists of sub elements that have a power driver (DP) value $\geq 0.5 \mathrm{X}$ and dependence value $(\mathrm{D}) \leq 0.5 \mathrm{X}$. Where $\mathrm{X}$ is the number of sub elements in each element.

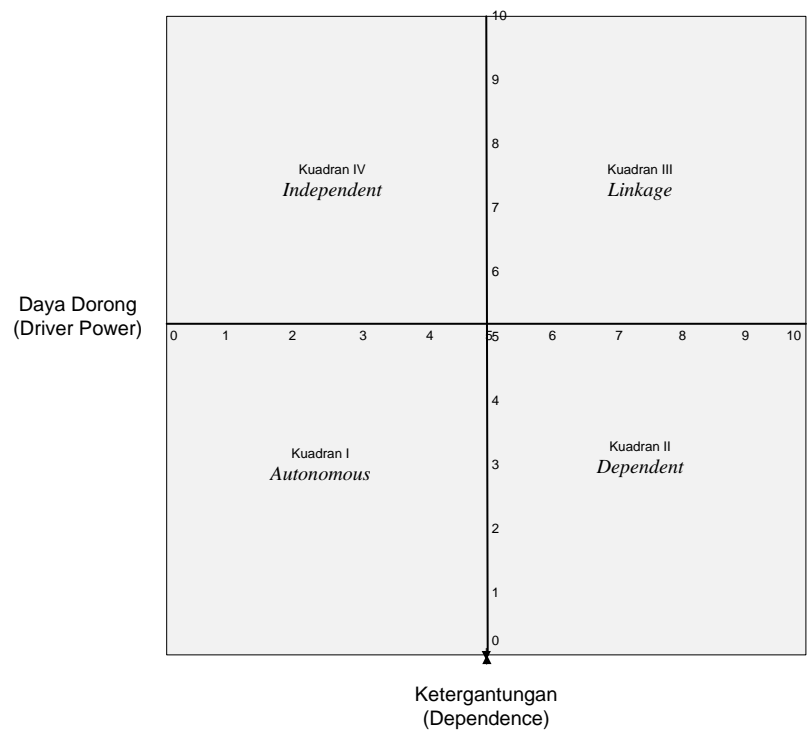

Figure 1. Driver Power and Dependence Matrix

\section{Result and Discussion}

Tanah Datar District has around 45 percent of the landslide hazard area. High population growth (1,6 percent) causes the use of land that is not suitable to be used or developed for settlements [3]. The study area has the characteristics of the area around 70 percent of the morphology of the hills. Based on the geology of the research area, it is an area of Bukit Barisan and Semangko faults.

Table 1. Land Use Change for The Period 2010-2017 in Tanah Datar District

\begin{tabular}{|c|c|c|c|c|c|c|c|c|}
\hline Land Use & Forest & Farm & Intercropping & Sattlement & Paddy & Swamp & Clearing & Total (ha) \\
\hline Forest & 75,864 & 1 & 0 & 0 & 0 & 0 & 0 & 75,865 \\
\hline Farm & 0 & 12,678 & 7,717 & 1,507 & 9,004 & 0 & 62 & 30,968 \\
\hline Settlement & 0 & 0 & 0 & 5,371 & 0 & 0 & 0 & 5,371 \\
\hline Paddy & 0 & 1,022 & 966 & 294 & 6,406 & 0 & 0 & 8,688 \\
\hline Swamp & 13 & 71 & 0 & 11 & 111 & 182 & 0 & 388 \\
\hline Total (ha) & 75,877 & 23,973 & 9,272 & 7,456 & 16,423 & 203 & 70 & \\
\hline
\end{tabular}

Source : Analysis (2018)

In Tanah Datar District the period of 2010-2018 has experienced changes in land use.In 2010 around 70 percent were forest areas, but this region experienced a reduction of 0.4 percent/year. Although the changes have no significant effect on landslides, this condition will be a threat to the future. 


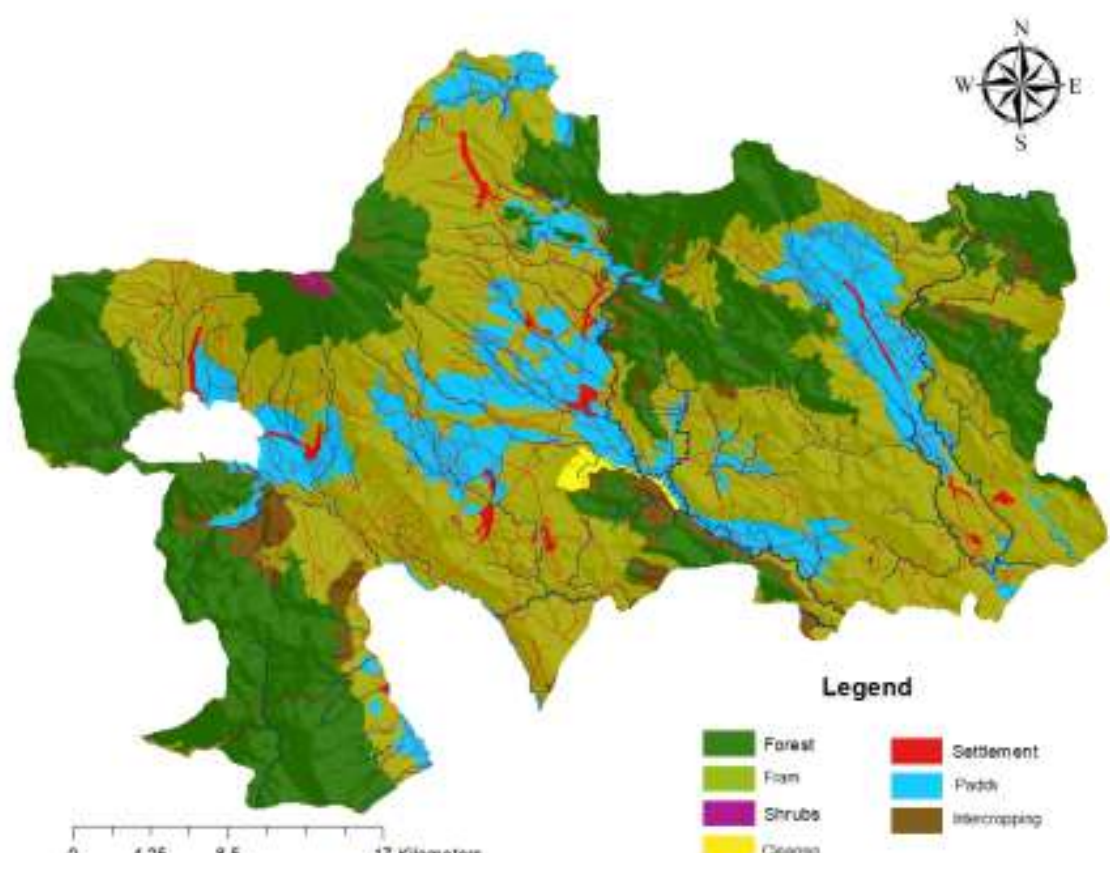

Figure 2 . Land use in Tanah Datar District (2010)

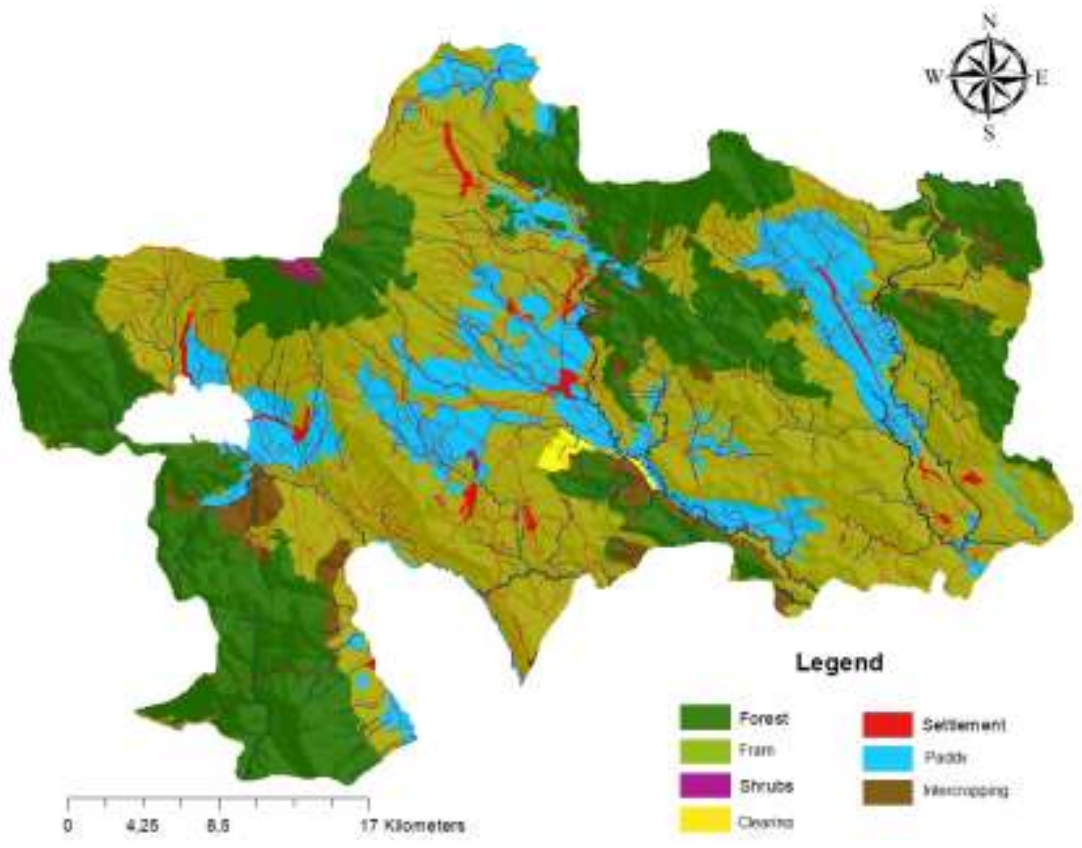

Figure 3. Land Use in Tanah Datar District (2017) 
The results of problem identification have four causal relationships, including: population growth, land use change, land needs, and policies. Population growth in the study area increased about 1 percent/year, and this problem caused land change about 1,4 percent/ year.

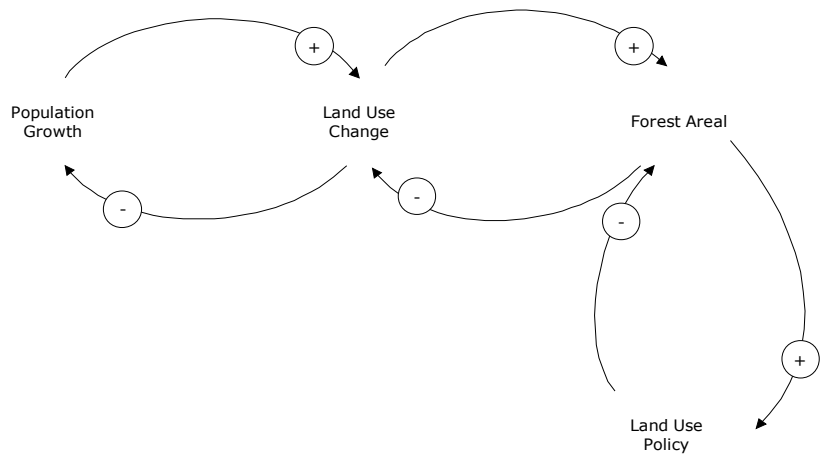

Figure 4. Causal Loop Dynamic Model Land Use Change in Tanah Datar District

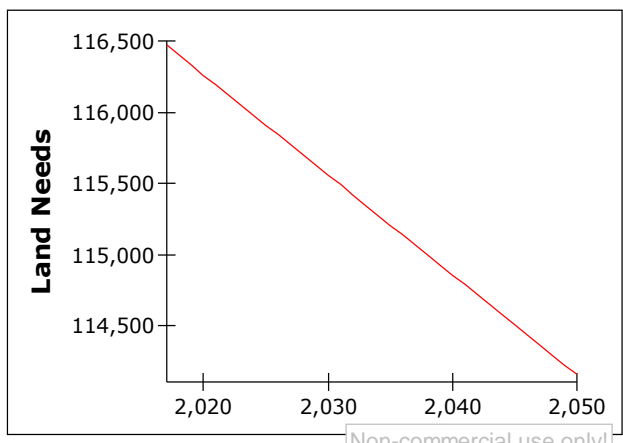

Figure 5. Graph Land Needs Impac Population Growth in Tanah Datar District

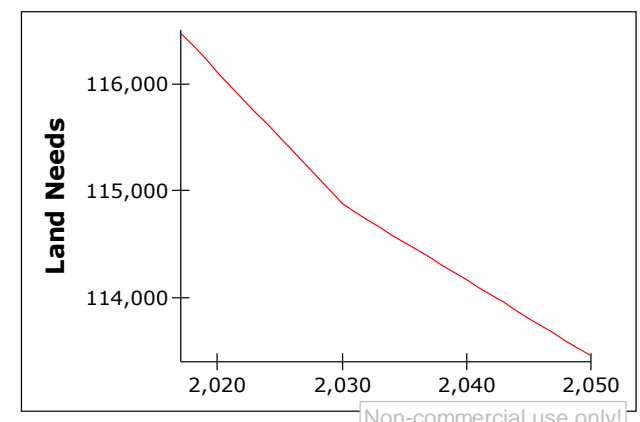

Figure 6. Graph of Land Needs for Government Policy Scenarios in Reducing Population Growth

The results of an analysis of 10 sub elements for the direction of spatial policy in Tanah Datar Regency indicate that two elements belong to the independent category (quadrant IV), and eight subelements are in quadrant III. Figure 8 presents that sub-elements of E7 consistency in the implementation of spatial plans and sub elements of E8 law enforcement in spatial violations have a high thrust (drive power). In addition, both sub elements have a low dependency value on other sub elements. 


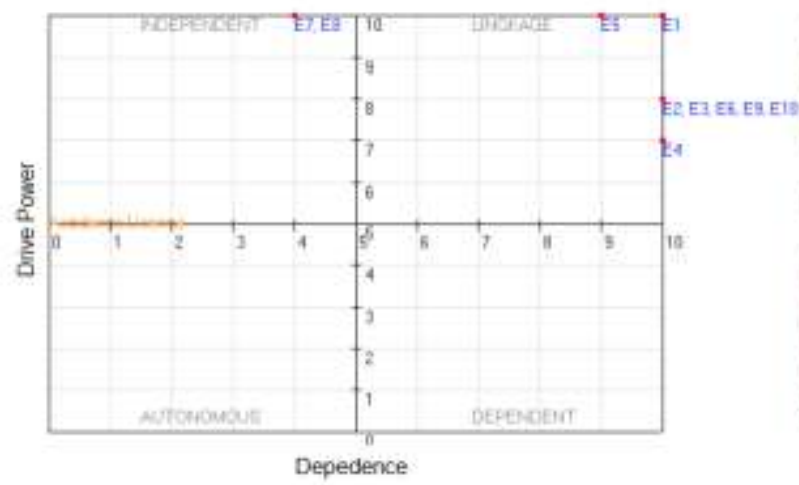

Legend

E1: Community based area plan

2: Making regulations and sanctions on spatial violations

E3: Synergy in making plans for space utilization between administrative regions

E4: Collaboration and synchronization between related institutions

E5: Socialization of the plan between the area

E6: Human Resource Development in spatial plans

E7: Consistency in the implementation of spatial plans

E8: Law enforcement in spatial violations

E9: Making more detailed space utilization plans

E10: Making technical standards for space use

Figure 7. Quadrant Drive Power and Dependence

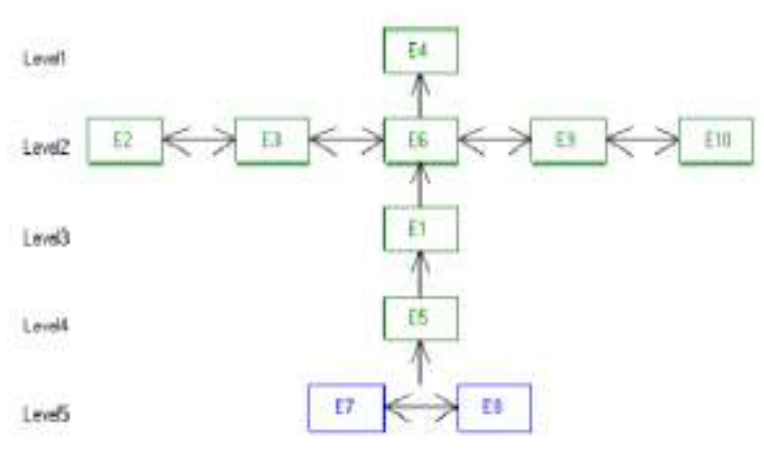
Legend
E1: Community based area plan
E2: Making regulations and sanctions on spatial violations
E3: Synergy in making plans for space utilization between administrative regions
E4: Collaboration and synchronization between related institutions
E5: Socialization of the plan between the area
E6: Human Resource Development in spatial plans
E7: Consistency in the implementation of spatial plans
E8: Law enforcement in spatial violations
E9: Making more detailed space utilization plans
E10: Making technical standards for space use

Figure 8. Land Use Policy Structure in Tanah Datar District

Figure 7 presents the implementation structure of the Tanah Datar District space utilization plan, there are five levels. At the highest level (level 5) there are two sub elements are sub elements of E7 consistency in the implementation of spatial plans and sub elements of E8 law enforcement in spatial violations. As a sub element of the summit, the two sub elements become the main policy in the direction of the implementation of spatial planning in Tanah Datar District.

\section{Conclusion}

The population growth of around 1.6 percent in Tanah Tanah District has an impact on land use. Settlement areas have increased every year, thus reducing water catchment areas. The implementation structure of the Tanah Datar District space utilization plan, there are five levels. And than the highest level there are two sub elements are sub elements of E7 consistency in the implementation of spatial plans and sub elements of E8 law enforcement in spatial violations. 


\section{References}

Abuzeinab, A., Arif, M., \& Qadri, M. A. (2017). Barriers to MNEs green business models in the UK construction sector: An ISM analysis. Journal of cleaner production, 160, 27-37.

Buol, S.W., F.D. Hole., and R.J. Cracken. 1980. Soil Genesis and Classification. Second Edition. The Iowa State University Press. Amess

[BPBD] Badan Penanggulangan Bencana Daerah Kabupaten Tanah Datar. 2017. Data Statistik Bencana Alam Kabupaten Tanah Datar.

Canuti, P., N.Casagli, and R. Fanti. 2003. Landslide Hazard for Archaeological Heritage: The Case of Tharros in Italy. Landslides News. 14/15: 40-43

Flentje, P., Chowdhury, R., 2016. Resilience and sustainability in the management of landslides. In: Proceedings of the Institution of Civil Engineers-Engineering Sustainability. Thomas Telford Ltd, pp. 1-12.

Glade, T. (2003). Landslide occurrence as a response to land use change: a review of evidence from New Zealand. Catena, 51(3-4), 297-314.

Harun, U.R. 1992. Dinamika Penggunaan Sumberdaya Lahan di Jawa Barat 1970-1990. Jurnal PWK. 3: 4853

Hermon, D. 2001. Studi Kontribusi Penggunaan Lahan dan Vegetasi Terhadap Karakteristik Epipedon. Tesis Magister. Program Pascasarjana Universitas Andalas Padang.

Hermon, D. 2009. Dinamika Permukiman dan Arahan Kebijakan Pengembangan Permukiman pada Kawasan Rawan Longsor di Kota Padang. Disertasi. IPB Bogor.

Hermon, D. 2010. Geografi Lingkungan: Perubahan Lingkungan Global. UNP Press.

Hermon, D. 2011. Studi Karakteristik Epipedon berdasarkan Penggunaan Lahan di Kecamatan X Koto Kabupaten Tanah Datar. Universitas Andalas.

Hermon, D. 2012. Dinamika Cadangan Karbon Akibat Perubahan Tutupan Lahan Permukiman di Kota Padang Sumatera Barat. Forum Geografi: Indonesian Juornal of Spatial and Regional Analysis. Volume 26. Issue 1. p: 45-52. Uniiversitas Muhammadiyah Surakarta.

Hermon, D. 2012. Mitigasi Bencana Hidrometeorlogi: Banjir, Longsor, Degradasi Lahan, Ekologi, Kekeringan, dan Puting Beliung. UNP Press. Padang.

Hermon, D. 2014. Impacts of Land Cover Change on Climate Trend in Padang Indonesia. Indonesian Journal of Geography. Volume 46. Issue 2. p: 138-142. Fakultas Geografi Universitas Gajah Mada.

Hermon, D. 2015. Geografi Bencana Alam. Jakarta: PT RajaGrafindo Persada.

Hermon, D. 2016. Mitigasi Perubahan Iklim. Rajawali Pers (Radjagrafindo).

Hermon, D. 2016. Estimate of Changes in Carbon Stocks Based on Land Cover Changes in the Leuser Ecosystem Area (LEA) Indonesia. Forum Geografi. Volume 29. Issue 2. p: 188-196.

Hermon, D. 2017. Climate Change Mitigation. Rajawali Pers (Radjagrafindo).

Hermon, D., Ganefri., A. Putra and O. Oktorie. 2018. The Model of Mangrove Land Cover Change for the Estimation of Blue Carbon Stock Change in Belitung Island-Indonesia. International Journal of Applied Environmental Sciences. Volume 13. Issue 2. p: 191-202. Research India Publication.

Hermon, D., Ganefri, Erianjoni, I. Dewata, P. Iskarni and Alexander Syam. 2019. A Policy Model of Adaptation Mitigation and Social Risks The Volcano Eruption Disaster of Sinabung in Karo Regency-Indonesia. International Journal of GEOMATE. Volume 17. Issue 60. p: 190-196. Geomate International Society.

Huang, Y., and Zhao, L. (2018). Review on landslide susceptibility mapping using support vector machines. CATENA, 165, 520-529.

Kaur, E., Palang, H., dan Soovali, H. 2004. Landscape in Change Opposing Attitudes in Saaremaa Estonia. Landscape and Urban Planing, 67(2): 109-120.

Kustiawan, I. 1997. Permasalahan Konversi Lahan Pertanian dan Implikasinya terhadap Penataan Ruang Wilayah. Studi Kasus: Wilayah Pantura Jawa Barat. Jurnal PWK. 8: 49-60 
Kristian, A and O. Oktorie. 2018. Study of Coastal Mangrove Conservation in the World. Sumatra Journal of Disaster, Geography and Geography Education. Volume 2. Issue 1. p: 49-52

Mai, T., \& Smith, C. (2018). Scenario-based planning for tourism development using system dynamic modelling: A case study of Cat Ba Island, Vietnam. Tourism Management, 68, 336-354.

Martono, D.N., Surlan, dan B.T. Sukmana. 2005. Aplikasi Data Penginderaan Jauh untuk Mendukung Perencanaan Tata Ruang di Indonesia. http://io.ppi.jepang.org/article

Mendoza, M. E., Granados, E. L., Geneletti, D., Pérez-Salicrup, D. R., \& Salinas, V. (2011). Analysing land cover and land use change processes at watershed level: a multitemporal study in the Lake Cuitzeo Watershed, Mexico (1975-2003). Applied Geography, 31(1), 237-250.

Oktorie, O. 2017. A Study of Landslide Areas Mitigation and Adaptation in Palupuah Subdistrict, Agam Regency, West Sumatra Province, Indonesia. Sumatra Journal of Disaster, Geography and Geography Education. Volume 1. Issue. 1. p: 43-49. Master Program of Geography Education.

Oktorie, O. 2018. Model Kebijakan Responsif Pemulihan Bencana Letusan Gunung Sinabung. Jurnal Kapita Selekta Geografi. Volume 1. Issue 1. p: 15-20

Pribadi, D.O., D. Shiddiq, dan M. Ermyanila. 2006. Model Perubahan Tutupan Lahan dan Faktor-Faktor yang Mempengaruhinya. Jurnal Teknologi Lingkungan. Pusat Pengkajian dan Penerapan Teknologi Lingkungan. 7: 35-51

Sitorus, S.R.P. 2005. Pengembangan Lahan Berpenutupan Tetap sebagai Kontrol terhadap Faktor Resiko Erosi dan Bencana Longsor. Makalah. Lokakarya Penataan Ruang sebagai Wahana untuk Meminimalkan Potensi Kejadian Bencana Longsor. Jakarta. 7 Maret 2006

Syahrin, A. 2003. Pengaturan Hukum dan Kebijakan Pembangunan Perumahan dan Permukiman Berkelanjutan. Pustaka Bangsa Press

Suryani, R.L. dan A. Marisa. 2005. Aspek-Aspek yang Mempengaruhi Masalah Permukiman di Perkotaan. Program Studi Arsitektur. Fakultas Teknik USU. Medan

Umar, I., Dewata, I., Barlian, E., dan Hermon, D. 2017. Zonasi Rawan Longsor Pada Kawasan Permukiman Di Kabupaten Tanah Datar. Prosiding Seminar Nasional DAS PKLH UNRI.

Umar, I. 2016. Mitigasi Bencana Banjir pada Kawasan Permukiman Di Kota Padang, Provinsi Sumatera Barat. Disertasi. Bogor: Sekolah Pascasarjana IPB.

Umar, I., dan Dewata, I. 2017. Pendekatan Sistem . Jakarta: Rajawali Press.

Utoyo, B.S., E. Anwar, I.M. Sandy, R.S. Saefulhakim, dan H. Santoso. 2001. Analisis Keterkaitan antara Pertumbuhan Wilayah dengan Pola Perubahan Struktur Penggunaan Lahan. Forum Pascsarjana. 24: $159-162$.

Virdin J.W. 2001. Understanding the Synergies between Climate Change and Desertification. UNDP

Xiao, J., Shen, Y., Ge, J., Tateishi, R., Tang, C., Liang, Y., et al. (2006). Evaluating urban expansion and land use change in Shijiazhuang, China, by using GIS and remote sensing. Landscape and Urban Planning, 75(1e2), 69e80. 